\title{
Analisis Kecepatan Aliran Air Berbasis Metode Laser Speckle Imaging
}

\author{
Havizzullah $^{*}$, Harmadi $^{* *}$, Marzuki $^{* * *}$ \\ Laboratorium Fisika Elektronika dan Instrumentasi, Jurusan Fisika \\ Kampus Unand Limau Manis, Padang, 25163 Indonesia \\ *havizzullah05@gmail.com \\ **harmadimsi@yahoo.co.id \\ ***marzuki14apr12@gmail.com
}

\begin{abstract}
ABSTRAK
Telah dilakukan analisis kecepatan aliran air dengan metode Laser Speckle Imaging (LSI). Sistem LSI menggunakan pendekatan forward scattering. Sistem terdiri dari tiga unit yaitu transmitter menggunakan laser He-Ne, receiver menggunakan CCD (Charge Couple Device), dan penampil menggunakan PC. Objek penelitian menggunakan air yang dijatuhkan dari wadah dengan diameter lubang yang divariasikan pada ketinggian yang berbeda. Hasil pengukuran kecepatan aliran air dari wadah berdiameter $1 \mathrm{~mm}$ pada ketinggian $50 \mathrm{~cm}$ memiliki nilai kecepatan terendah yaitu sebesar $0,73 \mathrm{ml} / \mathrm{detik}$. Nilai tertinggi dihasilkan dari wadah berdiameter $5 \mathrm{~mm}$ pada ketinggian $150 \mathrm{~cm}$ yaitu sebesar $15,49 \mathrm{ml} /$ detik. Ukuran diameter lubang dan ketinggian jatuh air semakin besar, maka nilai kecepatan aliran air semakin besar. Pengukuran intensitas citra juga dilakukan untuk melihat korelasi dengan kecepatan air. Nilai intensitas terendah yaitu 238,45 a.u diperoleh dari tetesan air dengan diameter $5 \mathrm{~mm}$ dan nilai tertinggi yaitu 253,12 a.u diperoleh pada diameter $1 \mathrm{~mm}$. Ukuran diameter wadah semakin besar maka nilai intensitas citra semakin kecil. Intensitas citra berbanding terbalik dengan nilai kecepatan aliran air.

Kata kunci : kecepatan alir, butiran hujan, intensitas citra, laser
\end{abstract}

\begin{abstract}
The rate velocity of rain drops has been analyzed by the Laser Speckle Imaging (LSI) method. LSI system uses a forward scattering approach to design. The system consists of three units namely the transmitter using the He-Ne laser, the receiver using a CCD (Charge Couple Device), and the viewer using a PC. Measurements are made using water dropped from containers with varying hole diameters at different heights. The application of the LSI method in measuring the speed of the hole diameter $1 \mathrm{~mm}$ at a height of $50 \mathrm{~cm}$ produces the lowest rate velocity value of $0.73 \mathrm{ml} / \mathrm{sec}$. The highest value is produced from containers $5 \mathrm{~mm}$ in diameter at an altitude of $150 \mathrm{~cm}$ which is $15.49 \mathrm{ml} / \mathrm{sec}$. This shows that the larger the size of the hole diameter and the height of falling water, the greater the velocity of the raindrop rate. Image intensity measurement is also done to see the correlation with the speed of water flow. The lowest intensity value is 238.45 a.u obtained from water droplets with a diameter of $5 \mathrm{~mm}$ and the highest value of 253.12 a.u obtained at a diameter of $1 \mathrm{~mm}$. The larger the diameter of the container, the smaller the intensity of the image. Intensity of the image is inversely proportional to the value of the velocity of water. Keywords: flow rate, raindrops, image intensity, laser
\end{abstract}

\section{PENDAHULUAN}

Hujan merupakan rangkaian proses dari siklus hidrologi. Pengetahuan tentang curah hujan dan karakteristik fisik curah hujan, sangat penting untuk mengetahui perkembangan dan perubahan siklus hidrologi. Parameter fisik hujan adalah ukuran yang terkait dengan volume dan kecepatan jatuh hujan (Fraile dkk., 2013).

Hujan merupakan salah satu bentuk dari presipitasi yang dapat berwujud cair maupun padat. Hujan di daerah tropis umumnya dalam bentuk butiran air, sedangkan pada cuaca yang ekstrim bisa berbentuk butiran-butiran kecil es (Permana, dkk., 2016). Hujan terdiri dari butiranbutiran air yang jatuh dengan kecepatan tertentu. Kecepatan curah hujan dipengaruhi oleh percepatan gravitasi, massa jenis air, ukuran butir air dan koefisien hambat udara. Pengukuran curah hujan sangat penting karena memiliki dampak luas terkait dengan, misalnya bahaya banjir dan erosi tanah (Testik dan Rahman, 2016). Nilai curah hujan yang diukur, dibutuhkan untuk memperkirakan dampak tersebut. Pengukuran kecepatan dibuat dengan ketepatan yang tinggi dan bisa menjadi dasar untuk tes empiris (Fraile dkk., 2013).

Metode pengukuran curah hujan yang telah dikembangkan dari penelitian sebelumnya, secara umum terbagi dua yaitu tipe observasi (non record) dan tipe otomatis (record). Metode tipe observasi yaitu pengukuran hujan dengan pengamatan. Prinsip kerja tipe ini yaitu menampung air hujan pada sebuah tabung penampungan berbentuk silinder, kemudian jumlah 
air yang tertampung dihitung per volume setiap terjungkit (Permana dkk., 2016). Perhitungan dilakukan berdasarkan setelah setiap penampung air penuh. Metode observasi memiliki kelemahan yaitu menggunakan peralatan dan perhitungan yang masih manual.

Pengukur tipe otomotis (record) merupakan alat pengukur curah hujan yang dapat menyimpan data pengukuran secara otomatis. Optical disdrometer dan Parsivel merupakan alat pengukur ukuran butir dan kecepatan hujan otomatis yang dilengkapi dengan transmitter dan unit penerima. Keunggulan Optical disdrometer yaitu kamera berkecepatan tinggi yang mampu merekam gambar rintik hujan saat melewati berkas cahaya (Testik dan Rahman, 2016) sehingga diharapkan data yang diseleksi memiliki error yang lebih kecil.

Pengukuran curah hujan dapat dilakukan dengan teknik optical seperti hamburan dan pencitraan. Salah satu teknik pencitraan dikembangkan oleh Kolte dan Ghonge (2016) menggunakan metode image processing melalui data pengamatan menggunakan video yang dikonversi ke bentuk frame. Hasil dari teknik ini terbatas pada jumlah tetesan dan volume hujan per frame, tetapi tidak dapat mengukur ukuran butiran hujan.

Penelitian sebelumnya dilakukan oleh Evita dkk (2010) dengan menciptakan rancangan alat pengukur kecepatan hujan otomatis tipe Tipping Bucket Rain Gauge berbasis mikrokontroler AT89S8252. Alat ini menghasilkan tetesan 0,21 mm untuk daerah tabung kecil sebagai penerima tetesan dari kerucut penampung air hujan seluas 2837,54 mm. Pengukur menggunakan sensor tipe reed switch dan dibaca oleh data logger berbasis mikrokontroler AT89S8252. Data logger tersebut dilengkapi sebuah real time clock dan komunikasi serial untuk mengirim data ke komputer. Kelemahan dari Tipping Bucket ini yaitu adanya kesalahan pada perhitungan ketika jumlah air dipenampung melebihi batas ketinggian maksimum.

Penelitian ini menganalisis kecepatan aliran air dari wadah berdiameter 1 sampai $5 \mathrm{~mm}$ berbasis metode laser speckle imaging menggunakan teknik pencitraan dengan pendekatan menggunakan software. Pengukuran dilakukan dengan video hasil rekaman. Proses pengambilan video menggunakan sistem perancangan dengan metode Laser Speckle Imaging dengan menganalisis citra. Citra dianalisis dengan anggapan bahwa partikel bergerak dalam satu arah sehingga posisi objek pada satu frame dibandingkan dengan data frame sebelumnya. Citra didapatkan dari butiran hujan yang jatuh melewati laser dan detektor Charge Couple Device (CCD). Detektor CCD ini akan merekam video yang didapatkan dan nantinya dikonversi kedalam bentuk frame menggunakan software. Metode LSI dipilih karena memiliki kesederhanaan dalam sistem perancangannya karena terdiri dari tiga komponen utama yaitu laser sebagai sumber cahaya, objek pengamatan dan CCD sebagai detektor. Teknik ini juga memiliki keunggulan yaitu rendahnya efek samping (non-dectructive, non-invasive, dan nonionitation), memiliki pencitraan penuh, akuisisi data langsung, akurat, kuantitatif dan biaya rendah.

\section{METODE PENELITIAN}

\subsection{Prosedur Penelitian}

Penelitian yang dilakukan adalah menganalisis kecepatan alir air dengan menggunakan metode LSI. Diagram alir penelitian dapat dilihat pada Gambar 1. 


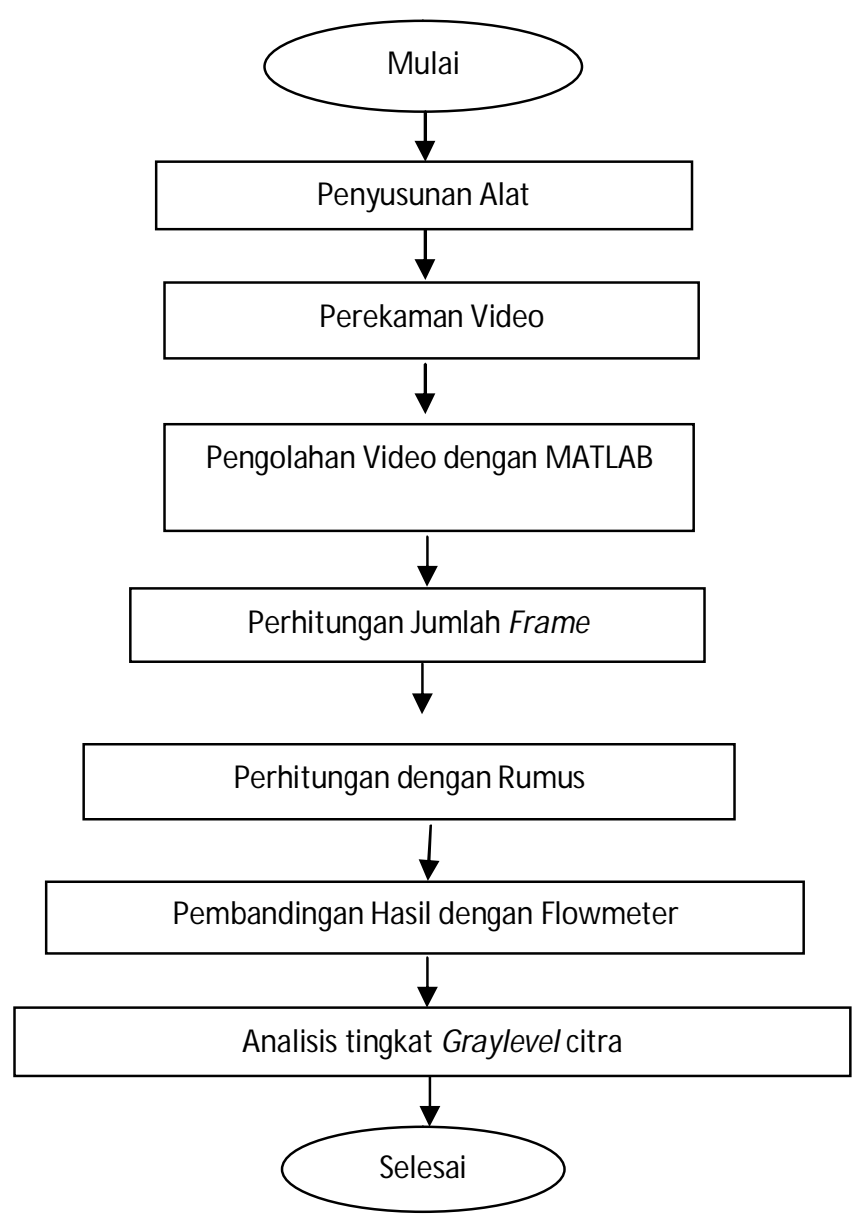

Gambar 1 Diagram alir

Sistem pencitraan optis digunakan untuk menghitung kecepatan aliran air, dengan menggunakan sumber cahaya dari Laser He-Ne yang memiliki intensitas lebih rendah dari cahaya tampak. Sumber cahaya yang diaplikasikan pada material bersifat tidak merusak (nondestructive) atau tidak memberikan efek nyata terhadap sampel. CCD digunakan untuk merekam gambar karena bersifat sensitif terhadap cahaya. Sistem komputer digunakan sebagai penampil pencitraan spekel dan menganalisis citra menggunakan sistem optical image processing (pengolahan citra optik), sehingga diperoleh nilai spekel.

\subsection{Rancang Bangun Sistim Pencitraan Optis}

Sistem rancang bangun pada metode LSI terdiri atas sebuah laser $\mathrm{He}-\mathrm{Ne}$ sebagai sumber cahaya, beem expander diposisikan didepan laser (sumber cahaya) untuk memfokuskan berkas laser. Berkas cahaya selanjutnya akan ditangkap oleh detektor. Penyusunan alat dalam metode LSI dapat dilihat pada Gambar 2.

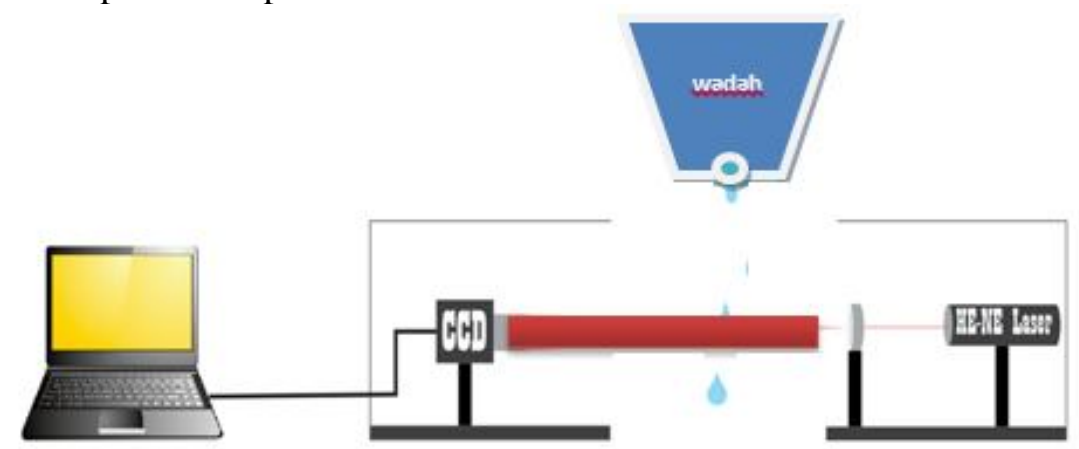

Gambar 2 Skema rancangan LSI 


\subsection{Pengolahan Citra Pola Spekel}

Pola spekel yang didapat dari tahap sebelumnya, kemudian diolah menggunakan image processing (pengolah citra) melalui intensitas histrogram graylevel (tingkat keabu-abuan) dari citra, sehingga dapat ditentukan kontras spekel. Pengolahan dilakukan menggunakan software MATLAB. Analisis nilai kontras spekel digunakan untuk membedakan citra tanpa hujan dan citra saat laser dilewati air dengan ukuran diameter lubang yang divariasikan.

\subsection{Analisis Pengukuran Kecepatan Aliran Air dan Pembandingan dengan Flowmeter}

Penelitian dilakukan menggunakan sampel berupa air dengan volume $200 \mathrm{~mL}$ yang dijatuhkan secara verikal melewati berkas cahaya laser. Air yang jatuh direkam dengan CCD yang dihubungkan ke PC menggunakan software Ulead VideoStudio 11. Kemampuan perekaman Ulead VideoStudio 11 adalah 29,97 fps. Hasil rekaman video selanjutnya dipecah menjadi frame. Frame yang bergambar adalah hasil pecahan video saat air melewati berkas laser. Frame dihitung sebagai fungsi waktu pengukuran kecepatan alir air menggunakan rumus fps (frame per second).

Pengukuran kecepatan aliran air menggunakan alat pembanding yaitu Flowmeter. Flowmeter merupakan jenis sensor pengukur kecepatan aliran air dan volume. Satuan yang digunakan pada flowmeter yaitu Liter/menit. Prinsip kerja Flowmeter yaitu adanya balingbaling yang berputar ketika dilewati air. Flowmeter hanya dapat mengukur kecepatan aliran dari 1 sampai 30 liter/menit. Flowmeter menggunakan Arduino Uno sebagai transmitter yang dihubungkan ke PC. Hasil pengukuran dapat dilihat pada serial monitor didalam software Arduino IDE. Pengukuran dilakukan dengan menjatuhkan air secara vertikal pada ketinggian $50 \mathrm{~cm}$ ke flowmeter.

\section{HASIL DAN DISKUSI}

\subsection{Pengukuran Intensitas Citra Spekel terhadap Variasi Diameter Lubang Jatuh Air}

Gambar Pengukuran nilai intensitas citra spekel diperlukan untuk menguji perubahan pola nilai kecepatan aliran air. Pengujian dilakukan dengan menjatuhkan air dari sebuah wadah berlubang tunggal, ukuran diameter lubang divariasikan dari $1 \mathrm{~mm}$ sampai $5 \mathrm{~mm}$. Pertama rekaman video diubah kedalam bentuk frame, dengan spesifikasi kamera 29,97 fps. Rekaman video berupa citra pola spekel dikonversi menjadi grayscale untuk memperoleh karakteristik histogram. Hasil pengolahan data dapat dilihat pada Gambar 3.

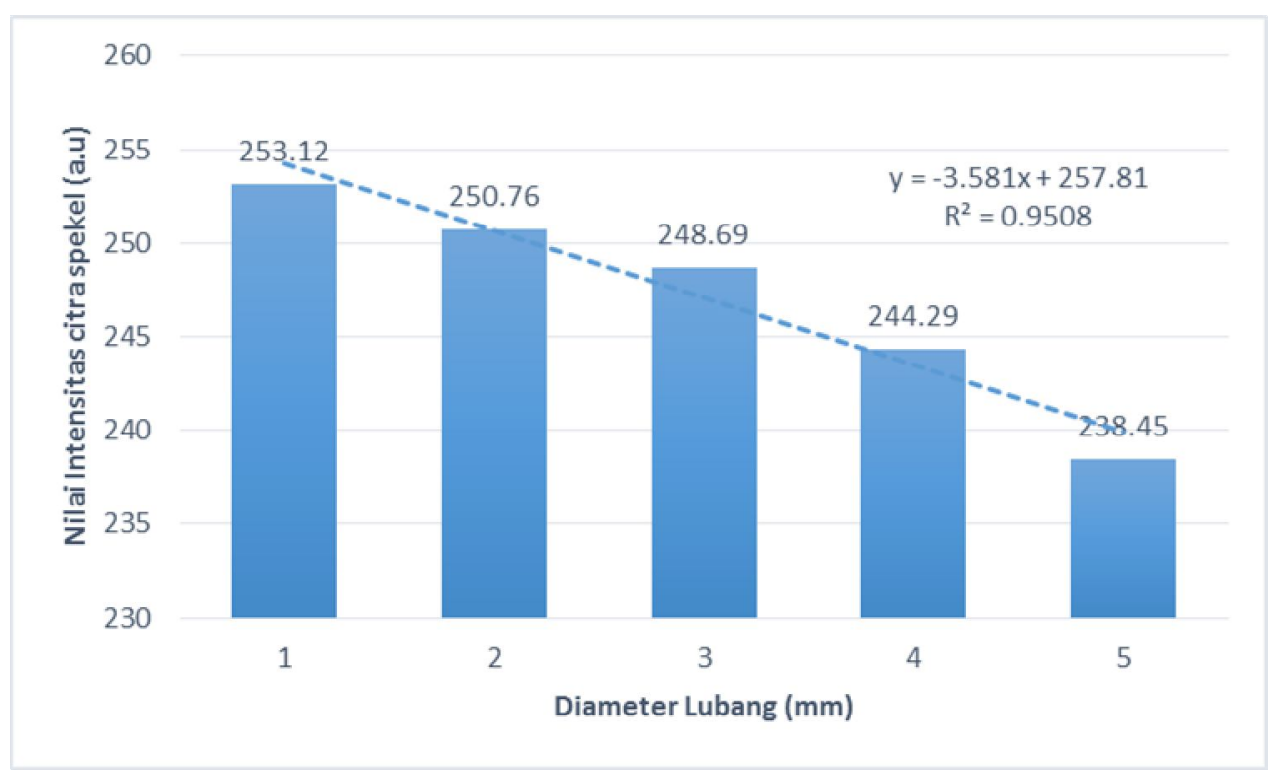

Gambar 3 Intensitas rata-rata spekel

Perubahan nilai intensitas spekel berbanding terbalik dengan besar diameter lubang jatuh air. Semakin besar diameter lubang jatuh air maka semakin kecil nilai intensitas spekel. 
Nilai intensitas terbesar didapatkan pada lubang berdiameter $1 \mathrm{~mm}$ dengan nilai 253,12 a.u, sedangkan nilai terkecil didapatkan pada lubang diameter 5 yaitu dengan nilai 238,45 a.u. Nilai koefisien korelasi $R^{2}=0,9508$ memperlihatkan adanya hubungan yang kuat antara intensitas rata-rata dengan ukuran diameter lubang jatuh air yang divariasikan.

\subsection{Pengukuran Kecepatan Aliran Air}

Perubahan nilai kecepatan aliran air terhadap ketinggian dan diameter lubang jatuh air merupakan parameter yang penting untuk mengetahui perubahan pola kecepatan aliran. Perubahan nilai kecepatan aliran air dilakukan dengan membandingkan semua data yang sudah diukur. Hasil pembandingan menunjukan bahwa semakin besar jarak ketinggian dan ukuran diameter lubang jatuh air maka nilai kecepatan aliran semakin besar. Semakin bertambah ukuran diameter lubang maka semakin besar volume air yang melewati. Nilai kecepatan aliran air meningkat dikarenakan volume air yang mengalir semakin besar. Perubahan nilai kecepatan aliran dapat dilihat pada Gambar 3.

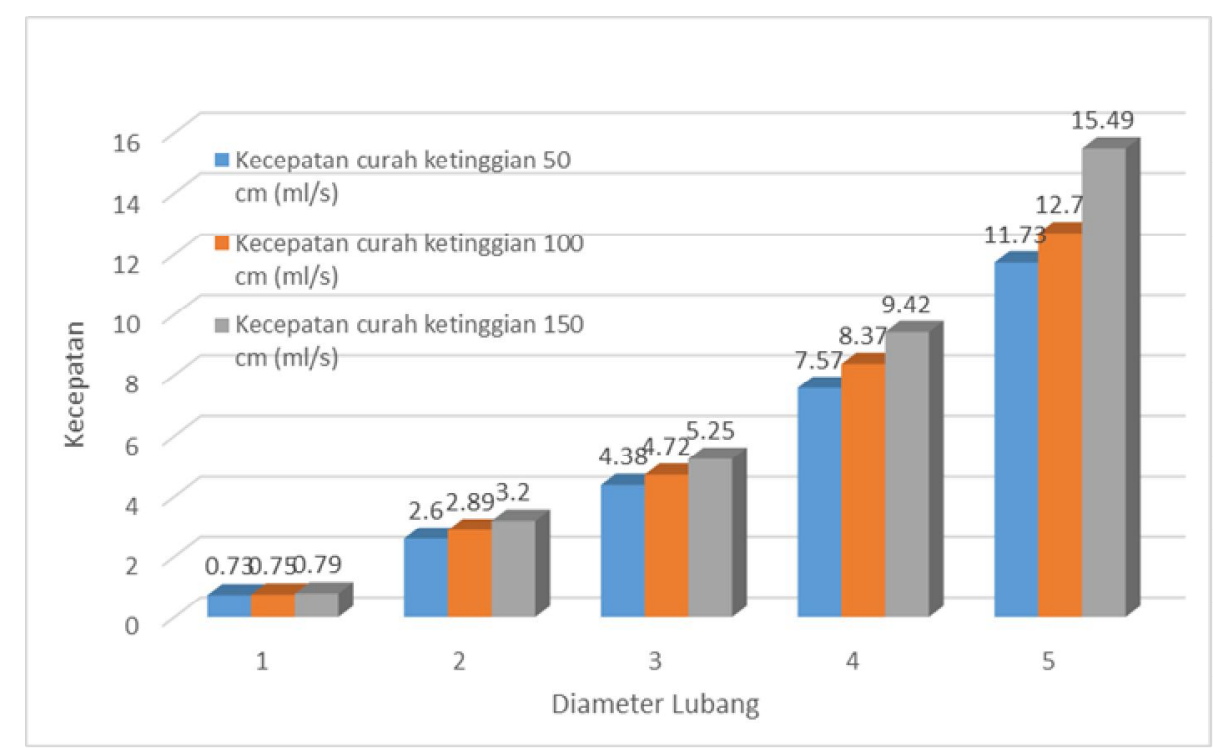

Gambar 3 Kecepatan Aliran Air Terhadap Ketinggian dan Diameter Lubang Air

Peningkatan kecepatan disetiap pertambahan ketinggian dan ukuran diameter lubang air. Kecepatan jatuh air dipengaruhi oleh gaya kebawah dan gaya hambat udara. Gaya hambat udara berpengaruh pada luas permukaan butiran air. Dalam penelitian ini, luas permukaan butiran air tidak berdampak secara signifikan dikarenakan tingkat ketinggian jatuh yang masih tergolong rendah jika dibandingkan dengan hujan. Sehingga gaya hambat udara tidak terjadi. Inilah kenapa semakin tinggi tempat jatuh air, maka nilai kecepatan aliran semakin meningkat dikarenakan hanya gaya kebawah yang bekerja, sedangkan gaya hambat udara tidak. Dari grafik diketahui bahwa nilai kecepatan aliran air terkecil berada pada ukuran diameter $1 \mathrm{~mm}$ dan ketinggian $50 \mathrm{~cm}$ yaitu dengan nilai $0,73 \mathrm{ml} / \mathrm{s}$. Peningkatan nilai kecepatan aliran terbesar terjadi pada ukuran diameter lubang $5 \mathrm{~mm}$ dan ketinggian $150 \mathrm{~cm}$ dengan nilai $15,49 \mathrm{ml} / \mathrm{s}$.

\section{KESIMPULAN}

Hasil pengukuran kecepatan aliran air berbanding lurus dengan ukuran diameter lubang jatuh air .Semakin besar ukuran diameter lubang maka nilai kecepatan aliran air semakin besar. Ukuran diameter wadah mempunyai korelasi yang kuat dengan peningkatan kecepatan aliran air. Pengukuran kecepatan aliran air berbanding lurus dengan ketinggian jatuh air, semakin tinggi jatuh air maka nilai kecepatan aliran air semakin besar. Nilai intensitas spekel berbanding terbalik dengan ukuran diameter lubang air. Semakin besar diameter lubang jatuh air maka semakin kecil nilai intensitas spekel. 


\section{DAFTAR PUSTAKA}

Evita.M, Mahfudz.H, Suprijadi, Jamal.M, Khairuurijal., Alat Ukur Curah Hujan Tipping-Bucket Sederhana dan Murah berbasis Mikrokontroler, J.Oto.Ktrl.Inst, 2, 2010.

Fraile.R, Castro.A, Raga.M.Fernandes, Palencia.C., dan Calvo.A.I., Error in the Sampling Area of An Optical Disdrometer, Consequences in Computing Rain Variables, The Scientific World Journal, 2013.

Kolte, G. dan Ghonge, P.A., An Image Processing Based Raindrop Parameter Estimation, International Journal Of Engineering trens and Technology (IJETT), 31, 73 - 77, 2016.

Permana, R.G., Rahmawati, E., dan Dzulkiflih., Perancangan dan Pengujian Penakar Hujan Tipe Tipping Bucket dengan Sensor Photo-Interrupter Berbasis Arduino, Jurnal Inovasi Fisika Indonesia, 4, 71 - 76, 2016.

Sawant, S., dan Ghonge, P.A., Estimation Of Rain Drop Analysis Using Image Processing,, International Journal Of Science and Research, 4, 1981 - 1986, 2015.

Testik, F.Y., dan Rahman, M.K., High-Speed Optical Disdrometer For Rainfall Microphysical Observations, Journal of Atmospheric and Oceanic Technology, 33, 231-243, 2016. 